\title{
Fostering Sustainable Development: A Corporate Social Responsibility Approach
}

\author{
Oluyomi A. Osobajo ${ }^{1}$, Olushola E. Ajide ${ }^{2} \&$ Afolabi Otitoju ${ }^{3}$ \\ ${ }^{1}$ Aberdeen Business School, Department of People, Organisations and Practice, Robert Gordon University, \\ Aberdeen, AB10 7QE, Scotland \\ ${ }^{2}$ FOL, Aberdeen, Scotland \\ ${ }^{3}$ Trinomial Solutions Ltd, Aberdeen, Scotland \\ Correspondence: Oluyomi A. Osobajo, Aberdeen Business School, Department of People, Organisations and \\ Practice, Robert Gordon University, Aberdeen, AB10 7QE, Scotland. E-mail: o.osobajo@rgu.ac.uk
}

Received: March 5, 2019 Accepted: June 20, 2019 Online Published: August 29, 2019

doi:10.5539/jms.v9n2p62ＵRL: https://doi.org/10.5539/jms.v9n2p62

\begin{abstract}
Corporate social responsibility (CSR) is the sacrificing of profits in the social interest of the public for sustainable management in an economical, ecological and social manner. It is the use of assets responsibly to create a competitive advantage and promote sustainable development. It is a series of interventions by companies to ameliorate externalized impact or the avoidance of conflicts. This article argues that CSR could be used as a tool for the attainment of sustainable development in the global south. Our aim is that companies should understand the critical role that CSR could play and adopt a corporate strategy that would use CSR to advance and enhance the value of the organization, thereby positively to impact the society.
\end{abstract}

Keywords: corporate social responsibility, sustainable development, corporations, oil and gas, Niger Delta, Nigeria

\section{Introduction and Background}

The impacts on society and environment by activities of Oil Producing Companies (OPC) are core to sustainability debates. In context, Africa continues to entice oil producing companies' notwithstanding political instability on the continent (Frynas, 1998). The investment of these 'hegemonic' institutions on the continent in 2017 was US\$46bn (PWC 2017). However, nations on the continent rank at the bottom ladder of human development index (Wolf-Christian, 2004; Furley, 1995). This OPC championed the waves of Corporate Social Responsibility (CSR) between the 1980s and the 1990s on the continent (Hilson, 2012; Frynas, 1998). CSR is the ethical behavior of a company towards society i.e. shareholders including a broader range of stakeholders who hold legitimate interests in the business (World Business Council for Sustainable Development, 1998). Nevertheless, Marsden and Andriof (1997) contend that sustainability is managing their relationships with society to curtail negative impacts and exploit positive benefits.

The presence of oil producing companies as 'social agents' in the face of continuous unrest and squalor in different parts of the continent creates a conundrum. The argument of the oil producing companies that they undertake CSR activities could be termed as lip service or 'public relation stunts'. While these companies argue that they are championing CSR in Africa, elsewhere they were found culpable and guilty for contravening the laws regarding the environment and preferred to pay a fine instead of compliance (Hilson, 2012; Landbein \& Kerwin, 1985). The population in rural communities across the continent bear the brunt of the adverse effects of the activities of these 'hegemonic' giants. Balland and Banks (2003 p. 293) argue that these corporations are "homogenous, powerful, hierarchical, rational, profit-seeking beasts." Moreover, in developing nations with a high number of rural communities these corporations wield significant influence on the physical, social and environmental resources (Goddard, 2005). Consequently, Shrivastava and Hart (1995) argue that these corporations' activities are unsustainable and therefore, they should ensure that their operations are with a high discretion towards social-environmental purposes. Despite some research on the CSR activities of oil producing companies on the continent, few studies have examined the sustainability of these investments (Mzembe \& Meaton, 2014). Moreover, challenges of food and water scarcity, climate change, ocean acidification, 
environmental pollution and the loss of biodiversity have not abated but instead are on the increase. The preceding arguments notwithstanding, this paper is not attributing the sole responsibilities to corporations in developing nations but rather that these organizations could ensure that sustainability underpins their operations. Also, they could use their influence to change government policies that would deliver sustainable development to rural communities in developing nations.

Drawing on the work of Donaldson and Dunfee (see for example: Donaldson \& Dunfee, 1994; Dunfee \& Donaldson, 1995; Donaldson \& Dunfee, 1999; Donaldson \& Dunfee, 2002) to make our argument that oil producing companies are agents of change in the global south and are instrumental for the attainment of the sustainable development goals. However, because of the duplicity in their modus operandi in the global south (e.g., Niger Delta) the desired goal of sustainable development has not been achieved in the region. Donaldson and Dunfee's emphasis on Macrosocial contract and Microsocial contract (Donaldson \& Dunfee, 1994) are especially useful to our analysis as it allows us to think through the interconnectivity between the normative contract and the implicit contract existing in the relationships within the Niger Delta. Such an understanding helps to comprehend the normative justification for business decisions by corporations within the region. Moreover, it helps one to know how such conclusions are drawn (Donaldson \& Dunfee, 1994, p. 254). To this end Donaldson and Dunfee's (1994) conceptualisation of Integrative Social Contracts Theory (ISCT) is generative for grasping how the "Core human rights, including those to personal freedom, physical security and well-being, political participation, informed consent, the ownership of property, the right to subsistence; and the obligation to respect the dignity of each human person" (Donaldson \& Dunfee, 1994, p. 267) within the Niger Delta is lacking. It is here also that Donaldson and Dunfee's attention to communities and their norms makes this approach most appropriate to sustainability issues. This is because it often involves competing for claims of different communities where dominant and subjugated knowledge is of value for informing humankind seek a binding. However, the unwritten agreement creates the limits for ethics in economic relationships, which is used by specific communities in appraising corporations' ethical behavior.

Having provided this insight into the theoretical lens that underpins this article, we now highlight the concept of Corporate Social Responsibility. Thereafter the need for and definition of sustainable development, the role of companies in sustainable development and the Niger Delta case study are now discussed and explained further. Conclusions are then drawn in the final section.

\section{The Concept of Corporate Social Responsibility}

Corporate social responsibility (CSR) has received excellent attention from researchers and scholars alike, who have agreed that the term "Corporate Social Responsibility" (CSR) has no single universal definition (Lockett et al., 2006; Blowfield \& Murray, 2008; McWilliams \& Siegel, 2011). Table 1 presents from the literature some of the CSR definitions suggested by existing scholars and researchers.

Table 1. Definitions of CSR (summarised from the literature)

\begin{tabular}{|c|c|}
\hline Drucker (1984, p. 62) & $\begin{array}{l}\text { "Is to turn a social problem into economic opportunity and economic benefit, into productive capacity, into } \\
\text { human competence, into well-paid jobs, into wealth". }\end{array}$ \\
\hline Wood (1991) & Suggests that society and business are interwoven rather than distinct entities. \\
\hline Fatehi $(1996$, p. 580) & Defines CSR as "obligations of business organizations toward society". \\
\hline $\begin{array}{l}\text { McWilliams \& Siegel } \\
(2001, \text { p. 1) }\end{array}$ & $\begin{array}{l}\text { "Is a situation where the firm goes beyond compliance and engages in actions that appear to further some } \\
\text { social good, beyond the interests of the firm and that which is required by law". }\end{array}$ \\
\hline Lea (2002) & $\begin{array}{l}\text { Include attempts and effort made by organizations to protect the environment i.e., community in which its } \\
\text { activities and operations are carried out, and how it interacts with such community. }\end{array}$ \\
\hline Baker (2003) & Focuses on how organizations manage the business processes to produce a positive impact on society. \\
\hline Hopkins (2003, p. 10) & "Is concerned with treating the stakeholders of the firm ethically or in a responsible manner". \\
\hline Hopkins (2003, p. 10) & "Means treating stakeholders in a manner deemed acceptable in civilized societies". \\
\hline $\begin{array}{l}\text { Kotler \& Lee }(2005, \mathrm{p} \text {. } \\
\text { 3) }\end{array}$ & $\begin{array}{l}\text { "Is a commitment to improving community well-being through discretionary business practices and } \\
\text { contributions of corporate resources" }\end{array}$ \\
\hline Hay $(2005$, p. 108) & $\begin{array}{l}\text { "Is a consistent pattern, at the very least, of private firms doing more than they are required to do under } \\
\text { applicable laws and regulations governing the environment, worker safety and health, and investments in the } \\
\text { communities in which they operate" }\end{array}$ \\
\hline $\begin{array}{l}\text { Werther Jr \& Chandler } \\
(2010)\end{array}$ & $\begin{array}{l}\text { IS the need for organizations to develop and maintain social legitimacy with the society in which they } \\
\text { operate }\end{array}$ \\
\hline
\end{tabular}

From Table 1, scholars' definition of CSR places emphasis on the role and obligations played by organizations towards society. Of crucial importance of this development is how the definition and focus of CSR have evolved 
(Garriga \& Melé, 2004; De Bakker et al., 2005). Carroll (1979, p. 500) whose definition of CSR is one of the most cited asserted that "the social responsibility of business encompasses the economic, legal, ethical and discretionary expectations that society has of organizations at a given point in time". This view further suggests that the essential role of an organization can be categorized into economic, legal, ethical, and discretionary roles. As a result, Carroll (1979) conceptualized these roles and responsibilities into a model of corporate social performance (CSP), which is capable of responding to the perceived societal issues. This is consistent with Piacentini et al (2000, p. 459) assertion that "performing in a socially responsible way involves companies responding to, and acting under the legal, moral and social concerns represented by company stakeholders".

Arguably, CSR is concerned with the wide-ranging responsibility of a firm for sustainable management in an economical, ecological and social dimension. The European Commission (2001) explicitly defined CSR as "a fundamental concept designed to help companies integrate social and ecological concerns into their corporate activities and relationships with stakeholders." Some scholars argue that CSR is the sacrificing of profits in the social interest (Elhauge, 2005; Zivin \& Small, 2005; Portney, 2005; Reinhardt, 2005), such a viewpoint positions CSR in a normative dimension. CSR as a concept has moved from being referred to as an obligatory role of organizations to an organization's strategic tool. Hence, it represents an essential concept in contemporary business and management practices. However, organizations are yet to perceive CSR as a strategic tool which could be used in fostering sustainable development. We would now consider the need for sustainable development in the next section.

\section{The Need for Sustainable Development}

The people of the Niger Delta Region of Nigeria solely rely on the environmental resources in the region for their social and economic sustenance. Due to the operations and activities of the various oil and gas companies operating in the region, sustainable development in the region has been perceived questionable. The WCED (1987) stated that "meeting the needs of the present should not compromise the ability of future generations in meeting their own needs" (WCED, 1987). However, the operations and activities of the oil and gas companies operating in the region have deprived the Niger Delta Region people the opportunity of benefiting from the diverse environmental and/or ecological zones (i.e., fresh water zones, mangrove swamp, rain forest and coastal island) within the region (Ross, 2012; Kadafa, 2012). This is consistent with scholars such as Renouard and Lado (2012), Ubani, and Onyejekwe (2013) assertion that the region is passing through a continuous and rapid deterioration, which was attributed to environmental degradation, social inequality, violence and conflicts, and cumulating poverty. Hence, the emergence of the current environmental degradation, economic challenges and social challenges in the region.

Also, Ubani and Onyejekwe (2013) stated that inadequate planning and management of the community and coastal development contributed to the decline in the region. Scholars such as Nriagu et al. (2016), Owolabi and Okonkwo (2015), Adelabu (2012), and Nyengidiki and Allagoa (2011) noted that the presence of oil and gas companies has resulted in widespread poverty and weak educational system in the region. Owolabi and Okonkwo (2015) and Renouard (2011) argued and concluded that the region is experiencing increases in social inequality, worsened health and economic condition, and water pollution and soil degradation, which has resulted in the reductions in wildlife and fisheries. Ite et al. (2013) and Ebegbulem, Ekpe, and Adejumo (2013) added that these outcomes are linked to the exploitation and production of oil and gas in the region. Hence, the resultant effect of oil producing companies' operations and activities by association. Eweje (2006) stated that the origin of environmental concerns in the region is because of oil exploration and production activities. Apata (2010) added that the presence of oil and gas companies has continued to be a source of environmental degradation in the region. This is in line with Elum, Mopipi and Henri-Ukoha (2016) assertion that the Niger Delta Region is experiencing persistent and disastrous gas flaring on its agricultural produce, which has resulted in abject poverty depriving the community people of their resource benefits. Equally, Idemudia and Osayande (2016) stated that the current situation in the region resulting from environmental degradation had given rise to undermined human development among the youth, while Olobaniyi and OmoIrabor (2016) concluded that the region is experiencing a decline in environmental and health conditions since the presence of the OPC. The region remains a source of continuous violence and conflicts between the Niger Delta Community people and the oil and gas producing companies (Aghedo, 2013; Obi, 2014). Arguably, these views suggest a need for sustainable development, which involves improvements to the environmental degradation, economic challenges and social challenges in the Niger Delta Region.

Sustainable development as a concept lacks a universally accepted definition (Schmuck \& Schultz, 2012). This suggests that the concept means different things to different people. This is consistent with Dempsey, Bramley, Power and Brown (2011) assertion that debates about sustainable development cover concerns such as economic, 
environmental and social dimensions. The World Commission on Environment and Development (WCED) (1987, p. 43) defined sustainable development as the development that meets "the needs of the present without compromising the ability of future generations to meet their own needs". This definition suggests that there is a need for the present generation to respect their environment in order not to deprive the future generation of such an environment. Also, the definition recognizes that interdependences, which promotes the concept of equity, must exist between the present and future generation. Hence, it is the responsibility of the present generation to respect environmental limits. Following the 1992 Earth Summit in Rio de Janeiro, there is general agreement that sustainable development requires the adoption of a comprehensive and integrated approach to economic, environmental and social processes (Banuri, Hyden, Banuri, Juma, \& Rivera, 2002; Najam, Rahman, Huq, \& Sokona, 2003; Dempsey et al., 2011).

Furthermore, Sachs and Reid (2006, p. 1002) defined sustainable development as an "economic growth that is environmentally sound". This definition suggests the importance of economic development and environmental development while considering sustainable development. This is because poor or lack of proper environmental development could undermine or limit economic development. This definition established a link between environmental development and economic development. Likewise, Schmuck and Schultz, (2012, p. 152) referred to sustainable development as "a means of improving or enhancing the quality of life while taking into consideration environmental quality". This definition suggests the need for social development from an environmental approach. Hence, a relationship is established between social development and environmental development. These views support the widely used three pillars of sustainable development: environmental, economic and social. Hence, an organization's sustainable policy should concentrate on transforming its pattern of operations or activities by focusing on correcting any resulting pollution and destruction from such activities or operations while generating societal models that emphasize the need for economic and social development.

\subsection{Overview of Sustainable Development Pillars}

More emphasis has been laid on the need for organizations to show concerns for sustainable development "in terms of realizing economic growth "that is forceful and at the same time socially and environmentally sustainable". This is consistent with Barkemeyer, Holt, Preuss, and Tsang (2014, p. 3) assertion that "the philosophical roots of sustainability lie within the 'environmental management' paradigm, whereby economic 'growth' can occur alongside improvements in social conditions". These views suggest that the pillars of sustainable development: environmental, economic and social complement one another. This is consistent with Harris (2000) assertion that because the economy constitutes an open system, it continually interacts with the environmental sphere, which encompasses the social system.

\subsubsection{Environmental Perspective}

Environmental sustainability aims at maximizing non-human welfare. A system is perceived to be environmentally sustainable when it avoids over-exploitation of the environmental resources to the extent to which adequate investment is made in substitutes and maintain a stable resource base. This includes the maintenance of biodiversity, atmospheric stability, and other ecosystem functions not ordinarily classed as economic resources (Harris, 2000).

\subsubsection{Economic Perspective}

Unlike environmental sustainability, economic sustainability focuses on maximizing human welfare such as clothing, food, housing, health, transportation and education services over time (Harris, 2000). This suggests that an economically sustainable system must be able to promote the production of goods and services that will support long-term goals into the future. Also, there will be a need for such system to maintain and uphold a manageable level of debt i.e., external and government debt, while avoiding imbalances among different sectors, which could damage industrial or agricultural production.

\subsubsection{Social Perspective}

Sachs $(1999$, p. 27) referred to social sustainability as a 'must rest on basic values of equity and democracy'. Likewise, Konning (2002) stated that the focus of social sustainability is on maintaining social values such as equity, culture and social justice. These views suggest that a socially sustainable system will promote an avenue for long-term interaction and human activity, which is inclusive, equitable and sustainable taking into consideration the broader view of environmental, economic and social dimensions.

\section{The Role of Companies in Sustainable Development}

Governments exist to ensure that the basic needs of the population are met. Within the sphere of society companies are set up to meet the specific needs of different groups. As such, it could be argued that both the 
government and corporations are partners in the delivery of sustainable development. However, business operations have both positive and negative impact on the environment and society at large. Therefore, government policies are supposed to reduce or prevent the negative impact of organizations on society. Furthermore, due to globalization and the retreat of the nation-state has propelled a more significant role to corporations and intergovernmental agencies (Aaronson 2009).

Also, an increase of awareness by the public and demand for enforcement of regulations including more disclosure by investors, regulators, and non-governmental organizations have induced a substantial role in increasing corporations' sensitivity to sustainability issues (Rondinelli \& Berry 2000). Likewise, expectations from public and shareholders on multifaceted social and economic issues in the host communities where these corporations operate have increased. (Rondinelli \& Berry, 1997). Moreover, to present an excellent corporate image and reputation to attract experienced recruits has made these firms to subscribe to sustainability. Other benefits include: customer loyalty and positive perception by governments and the entire citizenry. Nevertheless, the operations of these corporate entities have created the challenge of depletion of resources (Ciegis, Ramanauskiene, \& Martinkus 2015; Shrivastava, 1995; Pezzey, 1992) and exploitative power relations (Banerjee, 2010; Balland \& Banks, 2003) with particular reference in developing countries. The above factors have made these corporations to adopt and implement environmental management practices to lead to sustainable development (Rondinelli \& Berry, 2000). However, despite the subscription to these initiatives by these corporations the number of environmental degradation and socioeconomic dilemma continue to increase in the Niger Delta of Nigeria.

One could argue from an ethical perspective that every company should promote sustainable development. However, it is mandatory for organizations to be economically successful for continuity purposes (Laudal, 2010). This suggests the need to clarify the role of a company in sustainable development. It is generally agreed that companies embraced the notion of sustainable development (Barkemeyer et al., 2014). This could be attributed to the contributions made by companies such as multinational companies to their environment in the form of foreign direct investment, which promotes technology, capital and knowledge transfer for environmental, economic and social goals. However, scholars have debated and criticized the real contribution made by companies such as multi-national companies to their environment of operation as inconclusive (Lall, 2000; Benacek, Gronicki, Holland, \& Sass, 2000; Oetzel \& Doh, 2009). A number of these scholars have focused on the corporate environmental and social performance of companies, which covers areas such as pollution (Eskeland \& Harrison, 1997), multinational companies cross-border environmental management (Ruud, 2002), foreign direct investment and cleaner production (Wheeler, 2001), and impact of company operations on national environmental policies (Weidner \& Jänicke, 2002). Luken (2006) argued further that scholars' inconclusive result could be associated to lack or inadequate information, while Barkemeyer et al. (2014) concluded that foreign direct investment has resulted in increased capital inflows for some economies, knowledge and technology transfer, increased competitiveness and productivity gain and enhanced access for domestic companies to international markets. Likewise, negative impacts such as "the crowding out of domestic competitors and 'infant industries', low reinvestment levels, transfer pricing, asymmetries in bargaining power between large MNCs and weak developing country governments, or the creation of enclaves while failing to support large parts of the domestic economy, especially in the case of export processing zones" (Lall, 2000; Barkemeyer et al., 2014).

Furthermore, Eweje (2011) and Dahlsrud (2008) argued that companies could play an essential role in promoting sustainable development through corporate social responsibility. However, there are risks, opportunities and obligations associated with promoting sustainable development concerning environmental, economic and social success (Baumgartner, 2014). Even though, scholars have established a link between corporate social responsibility activities and company performance (McWilliams \& Siegel, 2011; Ditlev-Simonsen \& Midttun, 2011), there is less knowledge about how companies can be more sustainable (Baumgartner, 2014). Hence, sustainable development is perceived to be complex.

The concepts outlined above outlined what sustainable development is, and the role of companies in such a scenario, which will assist further in the evaluation of the state of sustainable development as practiced by oil producing companies in the Niger Delta. As earlier stated, Donaldson and Dunfee's (1994) Integrative Social Contracts Theory (ISCT) is the most helpful here. Thus, the next section considers the Niger Delta as a reference point in assessing sustainable development goals.

\section{The State of Sustainable Development in the Niger Delta}

Nigeria, which covers a total of 923769 sq. Km is situated within the Sub-Sahara African region shares borders 
with Chad and Niger to the north, the Republic of Benin to the west, the Gulf of Guinea to the south and Cameroon to the East. Nigeria has thirty-six independent states and a federal capital territory out of which nine states make up the Niger Delta region of Nigeria (NDRN). Figure 1 shows the NDRN, where almost $95 \%$ of the total oil and gas activities take place (Olajide, 2015; Daminabo \& Frank, 2015). However, Anambra and Lagos have been categorized as part of the oil producing states even though their respective production is not significant enough to alter the other nine states production (Oil \& Gas, 2016).

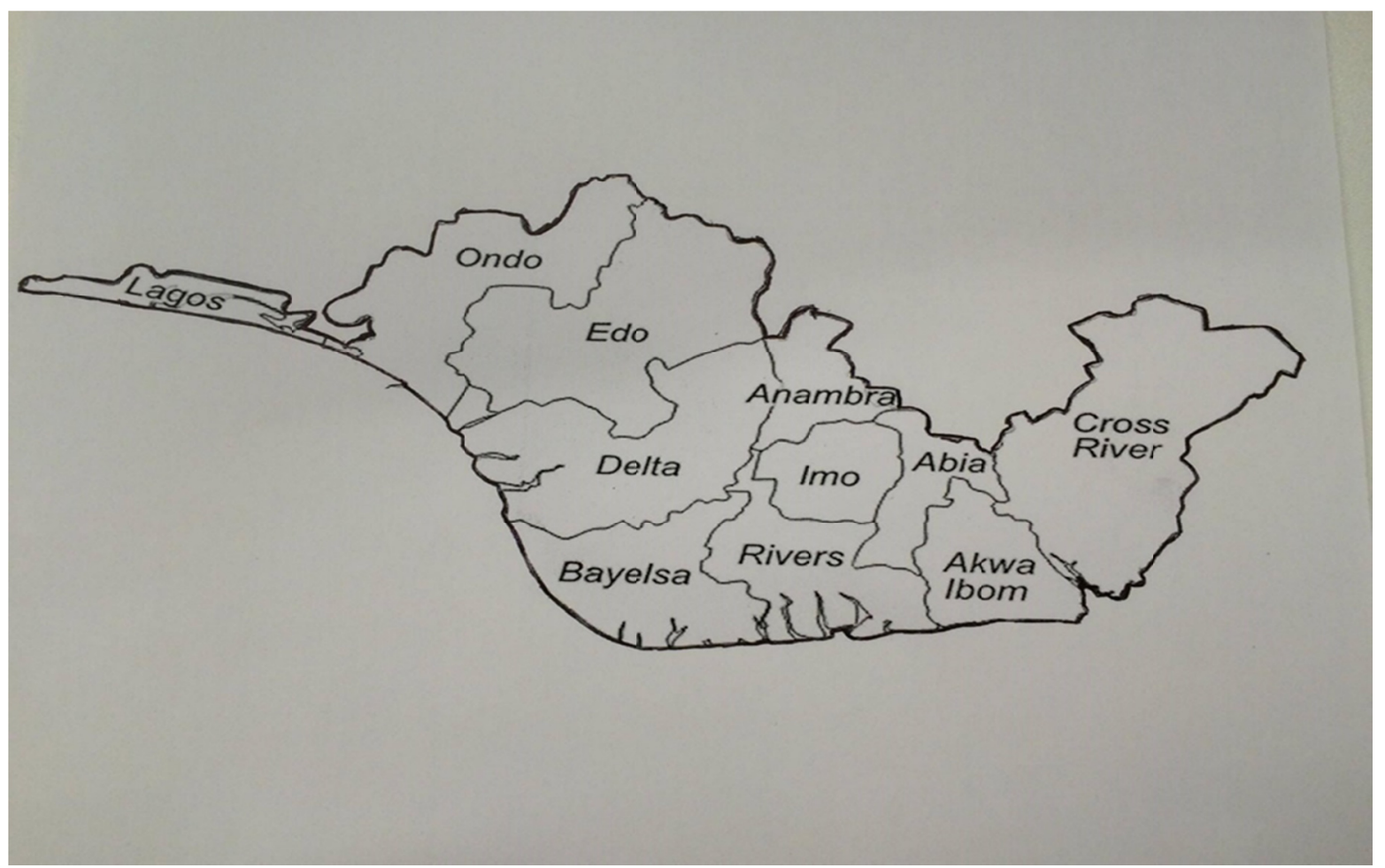

Figure 1. Map of oil-producing states in Nigeria (Osobajo, 2017)

Nigeria is the most populated Black Country with a population of about 178 million people (OPEC, 2015). Nigeria is referred to as the giant of Africa. Nigeria is endowed with the largest gas reserves in the world and seventh largest crude oil exporter in the continent (Agbonifo, 2016; Falode \& Udomboso, 2016). Hence, the source of her dominance in crude oil exportation among the African countries. The Nigerian government solely depend on the revenue from oil and gas exploration and production because Nigeria has consistently earned over $90 \%$ of her revenue from crude oil since the 1970s (Ikein, 2016; Okafor, Jegbefumwen, \& Ike, 2016). The Nigerian oil and gas industry are the primary source of attraction for the economy. This is because it accounts for about $95 \%$ of Nigeria's foreign exchange earnings, over $40 \%$ of the Nigerian economy gross domestic product and over $75 \%$ of the total revenue of the Federal government. Hence, the Federal government of Nigeria formulate appropriate policies and regulatory frameworks to attract foreign direct investments, encourage continuous production of oil and gas, and sustain the industry. With all the oil and gas resources Nigeria is endowed with, the financial benefits do not reflect in the life of its citizens (Watts, 2016; Elum et al., 2016; Kwaghe, 2015). Agbonifo (2016), and Falode and Udomboso (2016) added that over $85 \%$ of the natural gas is being flared in the NDRN. This has been a significant source of negative impact on the people of the NDRN and the Federal government revenue (Yunusa et al., 2016).

The NDRN is the home for 606 oil fields out of which 251 are offshore and the remaining 355 are onshore (NNPC, 2016). The region has an estimated population of over 40 million people with over $5 \%$ of the people living in rural areas (NDDC, 2010). Wurthmann (2006) argued that since the 1960s, oil revenue to the amount of $\$ 600$ billion worth has been generated from the region, yet the people of the region suffers from "administrative neglect, crumbling social infrastructure and services, high unemployment, social deprivation, abject poverty, filth and squalor, and endemic conflict" (UNDP, 2006). This has further led to the emergence of violence, conflicts and under-development in the region (Idemudia, 2010). This is in line with the Environmental Program 
(2011) who asserted that it would cost of over $\$ 30$ billion to be spent in the first 5 years through a recovery period of about 30 years to restore the degradation and damages caused by oil and gas activities in Ogoniland alone where oil and gas was first discovered in Nigeria. Table 2 presents information on pipeline and fire incidents, which are as a result of oil and gas activities in the country. Hence, Oyefusi (2013) concluded that the region is a subject of frequent violence and conflicts between the people and the oil and gas companies operating within the region.

Table 2. 5-year pipeline and fire incidents (NNPC, 2017)

\begin{tabular}{|c|c|c|c|c|c|c|c|c|c|c|}
\hline \multirow{2}{*}{$\begin{array}{l}\text { YEAR/ } \\
\text { AREA }\end{array}$} & \multicolumn{2}{|l|}{2013} & \multicolumn{2}{|l|}{2014} & \multicolumn{2}{|l|}{2015} & \multicolumn{2}{|l|}{2016} & \multicolumn{2}{|l|}{2017} \\
\hline & $\begin{array}{l}\text { Pipeline } \\
\text { Incidents }\end{array}$ & $\begin{array}{l}\text { Fire } \\
\text { Incidents }\end{array}$ & $\begin{array}{l}\text { Pipeline } \\
\text { Incidents }\end{array}$ & $\begin{array}{l}\text { Fire } \\
\text { Incidents }\end{array}$ & $\begin{array}{l}\text { Pipeline } \\
\text { Incidents }\end{array}$ & $\begin{array}{l}\text { Fire } \\
\text { Incidents }\end{array}$ & $\begin{array}{l}\text { Pipeline } \\
\text { Incidents }\end{array}$ & $\begin{array}{l}\text { Fire } \\
\text { Incidents }\end{array}$ & $\begin{array}{l}\text { Pipeline } \\
\text { Incidents }\end{array}$ & $\begin{array}{l}\text { Fire } \\
\text { Incidents }\end{array}$ \\
\hline $\mathrm{PH}$ & 640 & 5 & 269 & 1 & 921 & 3 & 1597 & 8 & 691 & 2 \\
\hline Warri & 317 & 10 & 378 & 13 & 254 & 5 & 217 & 2 & 37 & 2 \\
\hline Mosimi & 1080 & 3 & 1077 & 12 & 1114 & 11 & 398 & 6 & 71 & 2 \\
\hline Kaduna & 667 & 16 & 683 & 6 & 472 & 6 & 352 & 7 & 146 & 1 \\
\hline Gombe & 866 & - & 1325 & - & 71 & - & 25 & - & 60 & - \\
\hline Total & 3570 & 34 & 3732 & 32 & 2832 & 25 & 2589 & 23 & 1005 & 7 \\
\hline
\end{tabular}

In addition, maintaining a stable society is perceived to be an essential aspect of the economic development of any nation (Olson, 2008). The exploration and production of oil and gas resources have brought about both economic advantages as shown in table 3 and disadvantages as shown in table 4 to the people of the NDRN and Nigeria's economy with the economic disadvantage on the high increase. While the government has put in place a number of laws and regulations such as the Environmental Impact Assessment Act of 1992, which was enacted to protect the environment through the prevention of oil spillage and gas flaring, yet oil and gas companies operating in the region have been found to fall short of full compliance (Allen, 2012; Stewart, 2017). This is consistent with UNEP (2011) and Agbonifo (2016) assertion that oil spills in the NDRN continue to occur in alarming proportion.

Table 3. 10-year crude oil export in million barrels (NNPC, 2017)

\begin{tabular}{lllllllllll}
\hline YEAR & $\mathbf{2 0 0 8}$ & $\mathbf{2 0 0 9}$ & $\mathbf{2 0 1 0}$ & $\mathbf{2 0 1 1}$ & $\mathbf{2 0 1 2}$ & $\mathbf{2 0 1 3}$ & $\mathbf{2 0 1 4}$ & $\mathbf{2 0 1 5}$ & $\mathbf{2 0 1 6}$ & $\mathbf{2 0 1 7}$ \\
\hline PRODUCTION & 724 & 769 & 865 & 822 & 831 & 762 & 774 & 772 & 645 & 687 \\
\hline
\end{tabular}

Table 4. 5-year gas production and utilization (NNPC, 2017)

\begin{tabular}{llllll}
\hline YEAR & $\mathbf{2 0 1 3}$ & $\mathbf{2 0 1 4}$ & $\mathbf{2 0 1 5}$ & $\mathbf{2 0 1 6}$ & $\mathbf{2 0 1 7}$ \\
\hline GAS PRODUCTION & $2,325,137,449$ & $2,485,645,730$ & $2,929,852,323$ & $2,777,791,240$ & $2,901,632,487$ \\
GAS FLARED & $409,311,430$ & $285,761,600$ & $341,372,264$ & $312,468,060$ & $357,703,770$ \\
\% OF GAS FLARED & 17.6 & 11.5 & 11.65 & 11.25 & 12.33 \\
\hline
\end{tabular}

The current situation has further led to scholars and researchers agitation for the government to diversify into other sectors of the economy to put an end to the mono-economy created by the oil and gas industry (Izuchukwu, 2011). This is consistent with the International Monetary Fund (IMF) assertion that Nigeria must diversify into other sectors such as agriculture and manufacturing using public investments and market reforms (Sola \& Joachim, 2016; Ehie \& Muogboh, 2016). This was perceived as necessary to reduce the Nigeria economy's dependency on the oil and gas sector and the negative impacts of the sector. Hence, it becomes imperative for the various oil and gas companies operating in different business segments as shown in Figure 2 to find a lasting solution to the problems resulting from their presence in the region.

Furthermore, Ross (2003) asserted that the exploration and production of oil and gas resources had given rise to inequality in the region. This has further caused instability within the region's traditional institutions as community representatives who are perceived to be working against the oil and gas companies in the name of oil politics are remove from office (Watts, 2004). World Bank (2012) in its research argued and concluded that the emergence of oil and gas activities fuelled the increase in poverty levels within the region and the Nigerian economy. Hence, corruption and bribery have become the order of the day among the various stakeholders within the Nigeria oil and gas industry (Flinn, 2016; Cragg, Idemudia, \& Best, 2016). This has further led to the 
origin of armed insurgency in the region in which youths carry out terrorist attacks on the staff of the oil and gas companies.

One could argue from the foregoing that all the scenarios identified above have contributed to the devastating social implications for both the human element and infrastructure, non-fulfillment of the region's environment development potentials, and the deteriorating economic growth of the region, which are all necessary means of achieving sustainable development.

\section{Conclusion}

This paper contributes to the growing literature on CSR as a means of fostering sustainable development by providing a review of the concept, and associated concepts. CSR has the potential to promote sustainable development through the planning, implementing, monitoring, reviewing and controlling companies' sustainability activities. This suggests an awareness of the role companies' can play in sustainable development and the need for companies to consider the different pillars of sustainable development (i.e., environmental, economic and social dimensions) while implementing their CSR business strategies. The paper provides an overview of the various avenues through which companies could use CSR as a means of promoting sustainable development. Some of which include the ability of the companies to take into consideration factors such as environmental limits, upholding social equity and meeting human needs while implementing their CSR policies and agenda, which will evidence a company's understanding of sustainable development. In addition, the review suggested that CSR can position a company ahead of its competitors if developmental opportunities are identified and implemented sustainably. Furthermore, appropriate knowledge of CSR can aid practitioners and scholars alike in the identification and implementation of activities that can position a company to a sustainable company. Hence, one could conclude that CSR will foster sustainable development by suggesting avenues or means through which companies can be more sustainable.

\section{References}

Aaronson, S. A. (2009). Corporate Strategy and Inadequate Governance: The Pitfalls of CSR. World Bank Business and Development Discussion Paper, No. 11. https://doi.org/10.2139/ssrn.1439348

Agbonifo, P. E. (2016). Natural Gas Distribution Infrastructure and the Quest for Environmental Sustainability in the Niger Delta: The Prospect of Natural Gas Utilization in Nigeria. International Journal of Energy Economics and Policy, 6(3), 442-448

Allen, F. (2012). The enemy within: Oil in the Niger Delta. World Policy Journal, 29(4), 46-53. https://doi.org/10.1177/0740277512470928

Banerjee, S. B. (2010). Governing the Global Corporation. Business Ethics Quarterly, 20(2), 265-274. https://doi.org/10.5840/beq201020219

Banuri, T., Hydén, G., Juma, C., \& Rivera, M. (2002). Sustainable human development: from concept to operation: a guide for the practitioner. UNDP.

Barkemeyer, R., Holt, D., Preuss, L., \& Tsang, S. (2014). What happened to the 'development' in sustainable development? Business guidelines two decades after Brundtland. Sustainable development, 22(1), 15-32. https://doi.org/10.1002/sd.521

Baumgartner, R. J. (2014). Managing corporate sustainability and CSR: A conceptual framework combining values, strategies and instruments contributing to sustainable development. Corporate Social Responsibility and Environmental Management, 21(5), 258-271. https://doi.org/10.1002/csr.1336

Benacek, V., Gronicki, M., Holland, D., \& Sass, M. (2000). The Determinants and Impact of Foreign Direct Investment in Central and Eastern Europe: A comparison of survey and econometric evidence. Transnational Corporations, 9(3), 163-212.

Blowfield, M., \& Murray, A. (2008). Corporate responsibility: A critical introduction. New York, NY: Oxford University Press.

Ciegis, R., Ramanauskiene, J., \& Martinkus, B. (2015). The Concept of Sustainable Development and Its Use for Sustainability Scenarios. Engineering Economics, 62(2)

Cragg, W., Idemudia, U., \& Best, B. (2016). Confronting Corruption Using Integrity Pacts: The Case of Nigeria (pp. 297-322). Crime and Corruption in Organizations.

Dahlsrud, A. (2008). How corporate social responsibility is defined: An analysis of 37 definitions. Corporate Social Responsibility and Environmental Management, 15(1), 1-13. https://doi.org/10.1002/csr.132 
Daminabo, F., \& Frank, O. (2015). The Curse of Oil; The Unspoken Ecological and Environmental Devastation in the Niger Delta Region of Southern Nigeria. Journal of Sciences and Multidisciplinary Research, 7(1).

Dempsey, N., Bramley, G., Power, S., \& Brown, C. (2011). The social dimension of sustainable development: Defining urban social sustainability. Sustainable Development, 19(5), 289-300. https://doi.org/10.1002/sd.417

Ditlev - Simonsen, C. D., \& Midttun, A. (2011). What motivates managers to pursue corporate responsibility? A survey among key stakeholders. Corporate Social Responsibility and Environmental Management, 18(1), 25-38. https://doi.org/10.1002/csr.237

Donaldson, T., \& Dunfee, T. W. (1994). Toward a unified conception of business ethics: Integrative social contracts theory. Academy of Management Review, 19(2), 252-284. https://doi.org/10.5465/amr.1994.9410210749

Dunfee, T. W., Smith, N. C., \& Ross Jr, W. T. (1999). Social contracts and marketing ethics. Journal of Marketing, 63(3), 14-32. https://doi.org/10.1177/002224299906300302

Ebegbulem, J., Ekpe, D., \& Adejumo, T.O. (2013). Oil exploration and poverty in the Niger Delta Region of Nigeria: a critical analysis. International Journal of Business and Social Science, 3, 279-287

Ehie, I., \& Muogboh, O. (2016). Analysis of manufacturing strategy in developing countries: a sample survey of Nigerian manufacturers. Journal of Manufacturing Technology Management, 27(2), 234-260. https://doi.org/10.1108/JMTM-07-2014-0094

Elum, Z., Mopipi, K., \& Henri-Ukoha, A. (2016). Oil exploitation and its socioeconomic effects on the Niger Delta region of Nigeria. Environmental Science and Pollution Research, 23(13), 12880-12889. https://doi.org/10.1007/s11356-016-6864-1

Eskeland, G., \& Harrison, A. (1997). Moving to greener pastures? Multinationals and the pollution haven hypothesis, Policy Research Working Paper 1744. World Bank: Washington, D.C. https://doi.org/10.1596/1813-9450-1744

Eweje, G. (2011). A Shift in corporate practice? Facilitating sustainability strategy in companies. Corporate Social Responsibility and Environmental Management, 18(3), 125-136. https://doi.org/10.1002/csr.268

Falode, O., \& Udomboso, C. (2016). Predictive modeling of gas production, utilization and flaring in Nigeria using TSRM and TSNN: A comparative approach. Open Journal of Statistics, 6(01), 194. https://doi.org/10.4236/ojs.2016.61017

Frynas, J. G. (1998). Political Instability and Business: Focus on Shell in Nigeria. Third World Quarterly, 19(3), 457-478. https://doi.org/10.1080/01436599814343

Harris, J. M. (2000). Basic principles of sustainable development. Dimensions of Sustainable Development, 2141

Hilson, G. (2012). Corporate Social Responsibility in the Extractive Industries: Experiences from Developing Countries. Resources Policy, 37(2), 131-137. https://doi.org/10.1016/j.resourpol.2012.01.002

Idemudia, U. (2010). Rethinking the role of corporate social responsibility in the Nigerian oil conflict: The limits of CSR. Journal of International Development, 22(7), 833-845. https://doi.org/10.1002/jid.1644

Ikein, A. A. (2016). Nigeria oil \& external exposure: the crude gains and crude pains of crude export dependence economy. The Business \& Management Review, 7(3), 109.

Ite, A. E., Ibok, U. J., Ite, M. U., \& Petters, S. W. (2013). Petroleum exploration and production: Past and present environmental issues in the Nigeria's Niger Delta. American Journal of Environmental Protection, 1(4), 78-90. https://doi.org/10.12691/env-1-4-2

Izuchukwu, O. (2011). Analysis of the contribution of the agricultural sector on the Nigerian economic development. World Review of Business Research, 1(1), 191-200.

Kwaghe, Z. E. (2015). Black Gold and the Nigerian State (1956-2014): A Critical Review. Chinese Business Review, 14(2), 72-86. https://doi.org/10.17265/1537-1506/2015.02.002

Lall, S. (2000). FDI and development: research issues in the emerging context. Centre for International Economic Studies.

Laudal, T. (2010). An attempt to determine the CSR potential of the international clothing business. Journal of Business Ethics, 96(1), 63-77. https://doi.org/10.1007/s10551-010-0449-6 
Lockett, A., Moon, J., \& Visser, W. (2006). Corporate social responsibility in management research: focus, nature, salience and sources of influence. Journal of Management Studies, 43, 117-136. https://doi.org/10.1111/j.1467-6486.2006.00585.x

Luken, R. A. (2006). Where is developing country industry in sustainable development planning? Sustainable Development, 14(1), 46-61. https://doi.org/10.1002/sd.267

McWilliams, A., \& Siegel, D. S. (2011). Creating and capturing value: Strategic corporate social responsibility, resource-based theory, and sustainable competitive advantage. Journal of Management, 37(5), 1480-1495. https://doi.org/10.1177/0149206310385696

Najam, A., Rahman, A. A., Huq, S., \& Sokona, Y. (2003). Integrating sustainable development into the fourth assessment report of the Intergovernmental Panel on Climate Change. Climate Policy, 3(sup1), S9-S17. https://doi.org/10.1016/j.clipol.2003.10.003

NNPC. (2016). Development of Nigeria's oil industry (online). Retrieved from http://nnpcgroup.com/NNPCBusiness/BusinessInformation/OilGasinNigeria/DevelopmentoftheIndustry.asp $\mathrm{x}$

Nriagu, J., Udofia, E., Ekong, I., \& Ebuk, G. (2016). Health risks associated with oil pollution in the Niger Delta, Nigeria. International Journal of Environmental Research and Public Health, 13(3), 346. https://doi.org/10.3390/ijerph13030346

Oetzel, J., \& Doh, J. P. (2009). MNEs and development: a review and reconceptualization. Journal of World Business, 44(2), 108-120. https://doi.org/10.1016/j.jwb.2008.05.001

Oil \& Gas. (2016). Lagos officially joins the league of Oil Producing States in Nigeria (online). Retrieved from $\mathrm{http} / /$ www.ecofinagency.com/companies/1705-34403-lagos-officially-joins-the-league-of-oilproducing-stat es-in-nigeria

Okafor, S. O., Jegbefumwen, K., \& Ike, A. N. (2016). Human Capital Investment for Inclusive and Sustainable Economic Development: The Nigerian Experience. British Journal of Economics, Finance and Management Sciences, 11(1), 107-121.

Olajide, O. A. (2015). Understanding the complexity of factors which influence livelihoods of the urban poor in Lagos' informal settlements. Doctoral dissertation, Newcastle University.

Olson, M. (2008). The rise and decline of nations: Economic growth, stagflation, and social rigidities. Yale University Press.

Osobajo, O. A. (2017). Enhancing B2Com relationship quality: a research study investigating the oil producing company to host community relationship in the Niger Delta region of Nigeria. Doctoral dissertation, Robert Gordon University.

Oyefusi, A. (2013). Micro-Econometric Analyses of Some Welfare Effects of Oil-Availability in the Niger Delta Region of Nigeria. Journal of Sustainable Development, 6(12), 61. https://doi.org/10.5539/jsd.v6n12p61

Perrings, C. (2006). Resilience and sustainable development. Environment and Development Economics, 11(4), 417-427. https://doi.org/10.1017/S1355770X06003020

Pezzey, J. (1992). Sustainability: An Interdisciplinary Guide. Environmental Values, 1(4), 321-362. https://doi.org/10.3197/096327192776680034

Reinhardt, F. L., Stavins, R. N., \& Vietor, R. H. (2008). Corporate Social Responsibility through an Economic Lens. Review of Environmental Economics and Policy, 2(2), 219-239. https://doi.org/10.1093/reep/ren008

Sachs, J. D., \& Reid, W. V. (2006). Investments toward sustainable development. Science, 312(5776), 10021002. https://doi.org/10.1126/science.1124822

Schmuck, P., \& Schultz, W. P. (Eds.). (2012). Psychology of sustainable development. Springer Science \& Business Media.

Sola, A. K., \& Joachim, A. A. (2016). Development of the non-oil sector in Nigeria: challenges \& lessons for less developed countries. Covenant Journal of Business and Social Sciences, 5(1).

Spicer, A., Dunfee, T. W., \& Bailey, W. J. (2004). Does national context matter in ethical decision making? An empirical test of integrative social contracts theory. Academy of Management Journal, 47(4), 610-620. https://doi.org/10.5465/20159605 
Stewart, N. F. (2017). A Proposal of Reforms for Effective Environmental Management in Nigeria. Ajayi Crowther University Law Journal, 1(1).

Watts, M. (2004). Resource Curse? Governmentality, oil and power in the Niger Delta, Nigeria. Geopolitics, 9(1), 50-80. https://doi.org/10.1080/14650040412331307832

Watts, M. (2016). The Political Ecology of Oil and Gas in West Africa's Gulf of Guinea: State, Petroleum, and Conflict in Nigeria (pp. 559-584). The Palgrave Handbook of the International Political Economy of Energy. Springer. https://doi.org/10.1057/978-1-137-55631-8_23

Weidner, H., Jänicke, M., \& Jörgens, H. (Eds.). (2002). Capacity building in national environmental policy: A comparative study of 17 countries. Springer Science \& Business Media. https://doi.org/10.1007/978-3-662-04794-1

Wheeler, D. (2001). Racing to the Bottom? Foreign Investment and Air Pollution in Developing Countries. The Journal of Environment Development, 10(3), 225-245. https://doi.org/10.1177/10704965-0101003-02

World Bank Group. (2012). World Development Indicators 2012. World Bank Publications.

World Commission on Environment and Development (WCED). (1987). Our Common Future. New York: Oxford University Press.

Wurthmann, G. (2006). Working Paper 84-Ways of Using the African Oil Boom for Sustainable Development (No. 219).

Yunusa, N., Idris, I. T., Zango, A. G., \& Kibiya, M. U. (2016). Gas Flaring Effects and Revenue Made from Crude Oil in Nigeria. International Journal of Energy Economics and Policy, 6(3), 617-620.

Zivin, J. G., \& Small, A. (2005). A Modigliani-Miller theory of altruistic corporate social responsibility. The BE Journal of Economic Analysis \& Policy, 5(1). https://doi.org/10.1515/1538-0653.1369

\section{Copyrights}

Copyright for this article is retained by the author, with first publication rights granted to the journal.

This is an open-access article distributed under the terms and conditions of the Creative Commons Attribution license (http://creativecommons.org/licenses/by/4.0/). 